\title{
Fault-controlled geomorphic features in Ridi-Shantipur area of Gulmi District and their implications for active tectonics
}

\author{
*Kumar Timalsina and Kabi Raj Paudyal \\ Central Department of Geology, Tribhuvan University, Kirtipur, Kathmandu, Nepal \\ *Corresponding author: ktimilsina62@gmail.com
}

\begin{abstract}
The Lesser Himalaya is a fold-thrust belt in the Himalaya. In the Nepal Himalaya, several active faults, among which the Badi Gad Fault is one of them, are identified and mapped by many researchers in the past, However, very less study has been carried out on the existence of this fault and its extension. In the present study, an attempt was made to assess the fault and to map its extension in the region based on the geological as well as geomorphological criteria. For this purpose, a detailed geological map was prepared from Ridi to the Shantipur area in 1:25,000 scales. During the field work, several geological as well as geomorphic evidences of the existence of active fault were found, and some of them are also found under the aerial photo observation. These evidences include the presence of shear zones, clustering of large and several landslides along a confined linear zone, river course diversion, terrace tilting, fault scarps etc. In the present work, the Badi Gad Fault is traced out continuously from the Ridi to the Shantipur area and even extended far to the NW direction under aerial photo. The fault follows the moderate hills of the left bank of the present course of the Badi Gad River. Major shear zones found in the region are the Tal Khola, Aslewa, Eksingaun, Juhan, Gultung, and the Rupakot shear zones. These shear zones are represented by the wide zone of fault gauge, fault breccias, silickensides, striations and large landslides. Besides, other geomorphic evidences traced out are location of spring lines, tilted river terraces in Pul Camp and Wamitaksar area, river course diversion of the Lumdi Khola and fault scarp at Bhanjyangaun of Aslewa. Such types of fault-controlled geomorphic features are also found from the Rudrabeni-Wamitaksar areas under the aerial photos. Based on the fault controlled geomorphological study in the field and aerial photos interpretation, an attempt was made to map the Badi Gad Fault, an active strike slip fault in the region.
\end{abstract}

Keywords: Badi Gad Fault, Shear zones, Geomorphology, Aerial photo, Lesser Himalaya

Paper Received: 31 Jan 2018

Paper Accepted: 8 March 2018

\section{INTRODUCTION}

The Nepal Himalaya is the youngest mountain ranges in the world and it covers about one-third of the Himalayan arc $(800 \mathrm{~km})$. Due to tectonic collision between the Indian plate to the south and the Tibetan plate to the north, Himalaya was formed. From south to north the Nepal Himalaya can be divided into four tectonic zones as separated by the major thrusts like the Main Frontal Thrust (MFT), the Main Boundary Thrust (MBT), the Main Central Thrust (MCT) and the Southern Tibetan Detachment System (STDS) from south to north (Hagen, 1969). These master thrusts of the Himalaya have separated the five thrusting blocks viz. the Sub-Himalaya, the Lesser Himalaya, the Higher Himalaya and the Tibetan Tethys Himalaya respectively. Among them the Lesser Himalaya covers a large area in Nepal and the rocks of this tectonic unit are developed in two different geological setting: allochthons and autochthons to para-autochthons.

The study area lies in west-central part of Nepal and it forms a part of the inner belt of the Lesser Himalaya. The study area consists of mainly low-grade metasedimentary rocks. It is a fold-and-thrust belt in the Himalaya. Nakata et al. (1984), has mentioned four active faults in the Lesser Himalaya. Out of these faults, the Badi Gad Fault is one of them. It is stretching along the Kali Gandaki-Badi Gad corridor, which separates open and gently folded autochthonous Precambrian sediments with higher metamorphic grade to the northeast from intensely folded para-autochthonous and allochthonous younger sediments to the southwest, forming a major structural boundary between central and western Nepal (Arita et al., 1982). This active fault extends approximately in the NW-SE direction for about 140 $\mathrm{km}$ along the present course of the Badi Gad, Nishi Khola, Thulo Khola, Lukum Khola and the Sani Bheri Rivers. According to Arita et al., (1982) there is a Badi Gad Fault occurring along the Kali Gandaki-Badi Gad Khola, however, evidences of field data were very limited. Similarly, Nakata (1982) has studied the Badi Gad Fault in the western Nepal which extends for over $140 \mathrm{~km}$ in a NW-SE direction, and considered this fault to be one of the most active and important faults of the Lesser Himalayan Zone. It is interpreted to be an active fault with a right-lateral slip component. He has studied from the Wamitaksar to the Dobang area. Paudel (2012) studied the Badi Gad-Kali Gandaki Fault (BKF) and concluded that it is one of the most prominent and topographically well expressed structural features of central Nepal. The BKF runs parallel to the Badi Gad Khola 


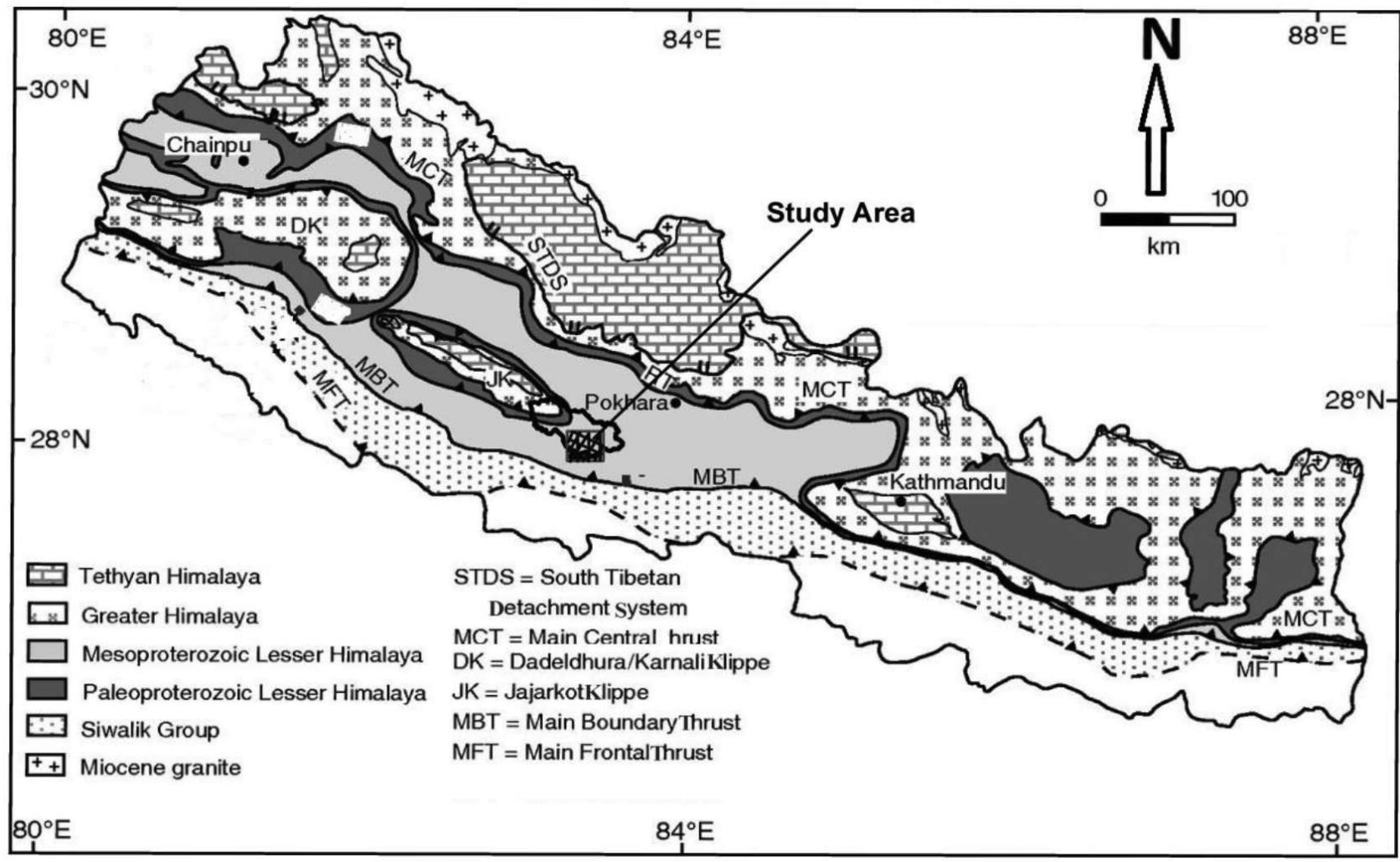

Fig. 1: Geological map of Nepal showing the location of the study area (modified after Amatya and Jnyawali, 1994)

in the west and the Kali Gandaki valley in the central and the eastern parts of the study area. Wherever the BKF passes across the ridges, a wide zone of topographic depression and active landslides express it. However, the present area i.e. RidiShantipur area, (near the SE) has not been studied by previous researchers at that time. To fulfill this gap, the current study was selected as a continuous work of the previous researches.

Geomorphology is the scientific study of landscapes and the processes that shape them. The science of geomorphology has two major goals. One is to organize and systematize the description of landscape by intellectually acceptable schemes of classification. The other is to recognize in landscapes evidence for changes in the processes that are shaping and have shaped them (Bloom, 2002). The broad objective of the present study was to carry out the detail geomorphologic study of the RidiShantipur area with the aim to assess the presence of the Badi Gad Fault. The specific objective was to map the location and extension of the Badi Gad Fault on the basis of geomorphic as well as geological criteria. To examine these fault-related features extensive field work was carried out along the territory of the Badi Gad Khola. An attempt was also made to interpret the aerial photos at the same time. The study area lies in the vicinity of the Ridi Bazar way to Rudrabani, Khairani to Shantipur, north-west of the Kali Gandaki Nadi, and both left and right bank hills of the Badi Gad Khola. The study area covers the southern and eastern parts of the Gulmi District with a total area of about 245 sq. km (Fig. 1).

\section{METHODOLOGY}

The study was broadly categorised into four parts as: (i) desk study, (ii) field work, (iii) laboratory work and (iv) data processing and interpretation. The topo-sheet of Ridi (sheet no. 2783 02B) and Bharsegau (sheet no. 2883 14D), and aerial photographs were used for the study. Primary geological data were collected especially focusing on the preparation of geological maps as well as geomorphological features. Geological traverse was made along rivers, streams, ridges and all possible foot trails to prepare a geological map of the study area (Fig. 2). The names of the stratigraphic units were adopted from the central Nepal Lesser Himalaya (Stöcklin and Bhattarai 1977, Paudyal, 2014).

Necessary geomorphic features like stream offsets, offset ridges, terrace tilt, active landslides etc. were observed and photographs were taken by digital camera. Morphometric as well as geological parameters such as drainage pattern, relief, presence of landslides, fault-related features, shear zones etc. were surveyed in the field. Seven pairs of aerial photographs were studied for the location of active fault. Morphometric and geological maps, longitudinal profiles, cross- sections and slope maps were prepared using the software like Geographic Information System (GIS), Coral Draw, Macromedia Freehand and Adobe Photoshop. Finally, all these data were compiled from field work and analyzed for the interpretation. 


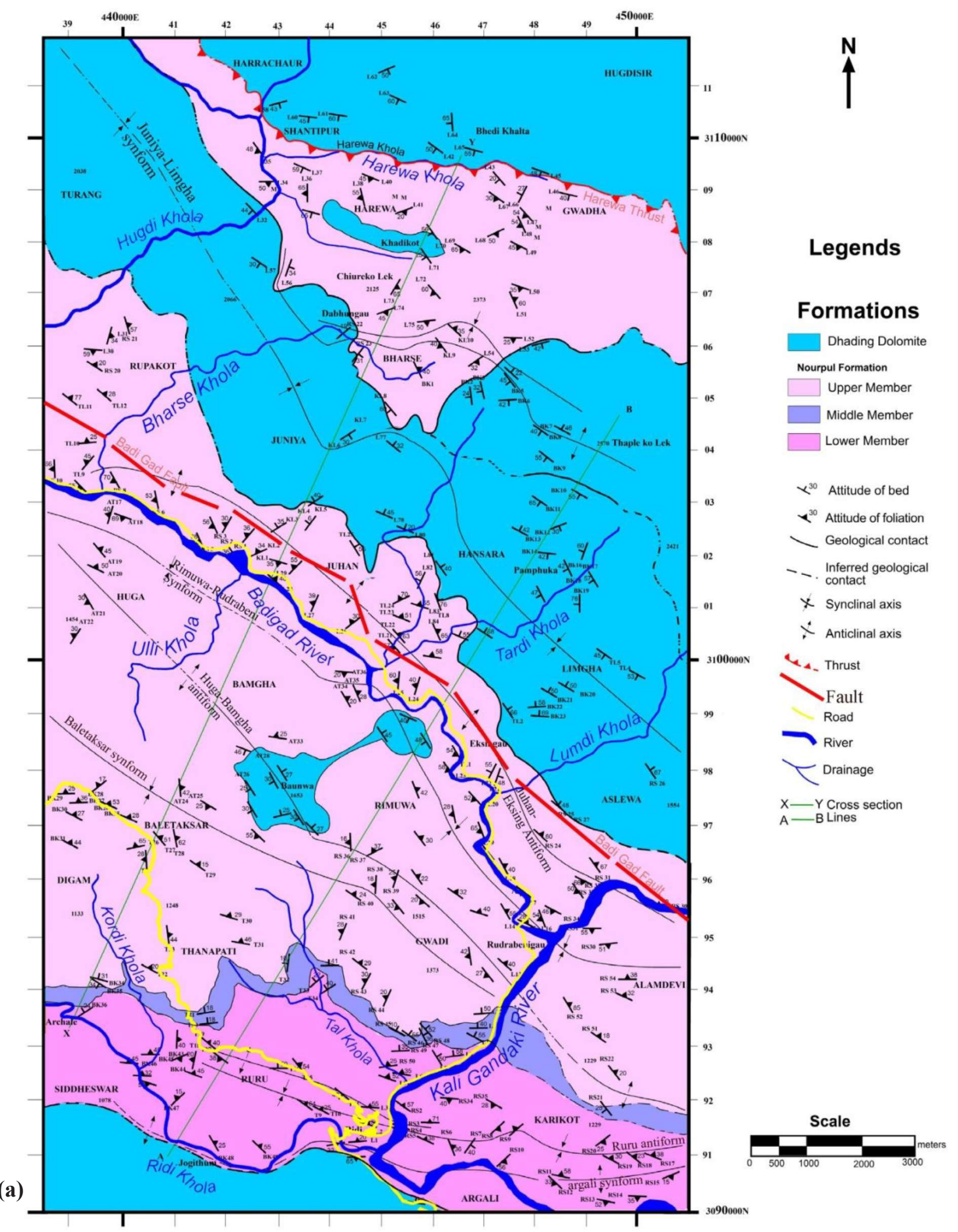

Fig. 2: (a) Geological map of Ridi-Shantipur area (prepared by A. M. Rai, B. Rana Bhat, B. Yogal, M. S. Chaudhary, R. S. Pyakurel, S. S. Khadka, S. Shakya, S. B. Thakuri, and authors of this paper) 


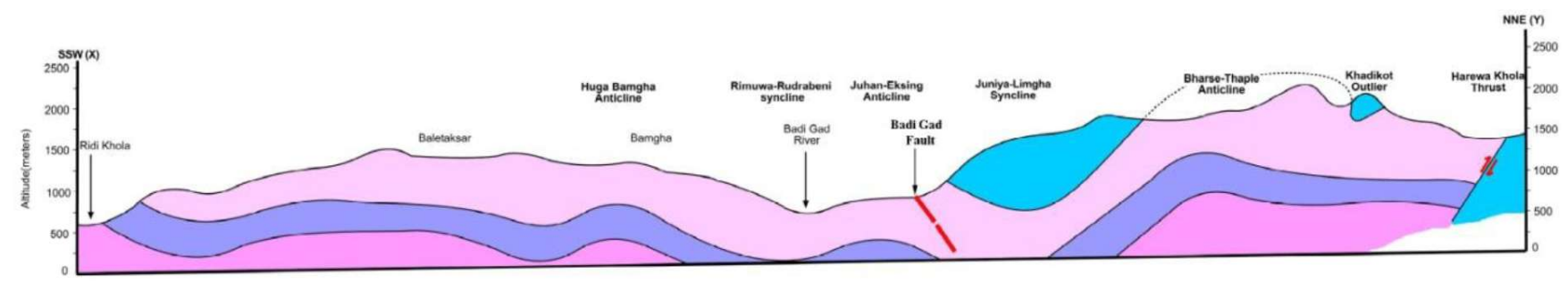

(b)

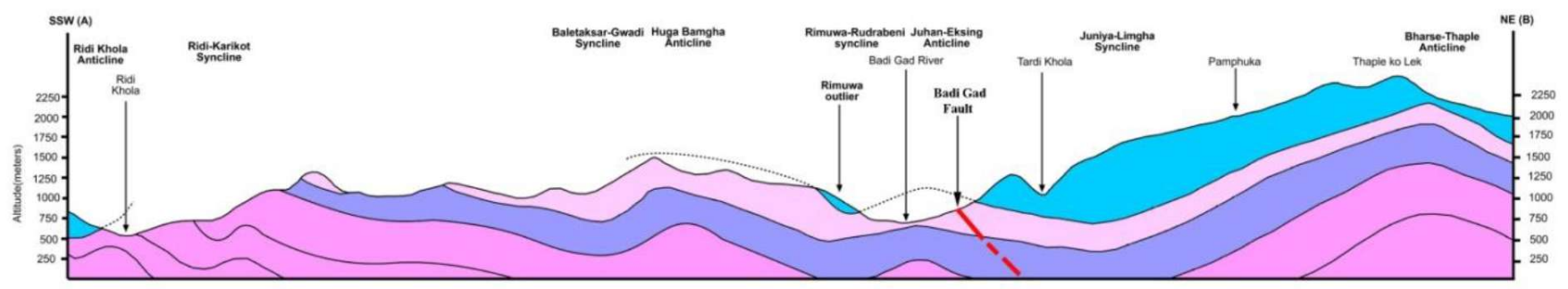

(c)

Fig. 2: (b) Cross-section along the line X-Y Y (Archale to Bhedi Khola), and (c) Cross-section along the line A-B (Ridi Khola to Thaple ko lek)

\section{RESULTS}

\section{Lithostratigraphy}

The rocks of the region have been mapped into two units: the Nourpul Formation and the Dhading Dolomite (Fig. 2). The Nourpul Formation consists of the succession of phyllite and metasandstone with subordinates of quartzite and dolomite while the Dhading Dolomite is monotonous unit of dolomite with minor amounts of phyllite and quartzite. The former unit has formed mostly the gentle lands while the later unit has formed ridges and cliffs in the area.

\section{Geological structures}

The most remarkable structure found in the area are the shear zones in various scales. One of the prominent shear zone is found in the contact between the Nourpul Formation and the Dhading Dolomite (Figs. 3a and 3b). The names of these shear zones were taken from the geographical names where such zones were mapped. These shear zones are clustering along a certain region, extending from the Tal Khola, Aslewa, Eksingau, Juhan, Gultung and Rupakot (Fig. 2). Six prominent shear zones mapped in the area and are described in the following sections.

\section{Tal Khola Shear Zone (TS)}

About $3 \mathrm{~km}$ NE from the Ridi Bazar, at the right bank of the Kali Gandaki Nadi, the Tal Khola Shear Zone was observed. A clear evidence of shearing as indicated by the brecciated mass, gouge material, striations and minor displacements is seen in pelitic phyllite succession. In this shear zone, s-type and z-type of folds were also observed (Fig. 4).

\section{Aslewa Shear Zone (AS)}

It lies in Aslewa VDC, at the left bank of the Badi Gad Khola. As shear indicators, good exposure of fault gouge, fault breccia and slickensides were observed (Fig. 5). Several cracks have been developed in the Ram Mandir (a famous temple) in Rudrabeni that lies adjacent to this shear zone.

\section{Eksingau Shear Zone (ES)}

The Eksingau Shear Zone lies in the village of Eksingau and Pipal Dada area of Limgha VDC. In this area, a large active landslide was observed. Geological contact of the Nourpul Formation and the Dhading Dolomite also passes from the middle part of the landslide. The most remarkable feature is the extensive development of fault breccias, slicken sides and fault gauge. Spring lines are also developed in the region.

\section{Juhan Shear Zone (JS)}

At the left bank of the Badi Gad Khola and uphill section of Hansara VDC, another large shear zone was observed (Fig. 6). This shear zone has caused a large landslide in Juhan-Hatiya area. Shear related features like striations, grooves and fault breccias are abundant in the area. This landslide is also called "Dhule Pahiro" in the area as it is ever active even during the sun shine days.

\section{Gultung Shear Zone (GS)}

The Gultung shear zone lies at about $500 \mathrm{~m}$ upstream from Ulli Khola Bazar on the left bank of the Badi Gad Khola. It covers about 500-1000 $\mathrm{m}$ area in Juniya VDC. The indications of shearing like silickensides, breccias and step-marks were 

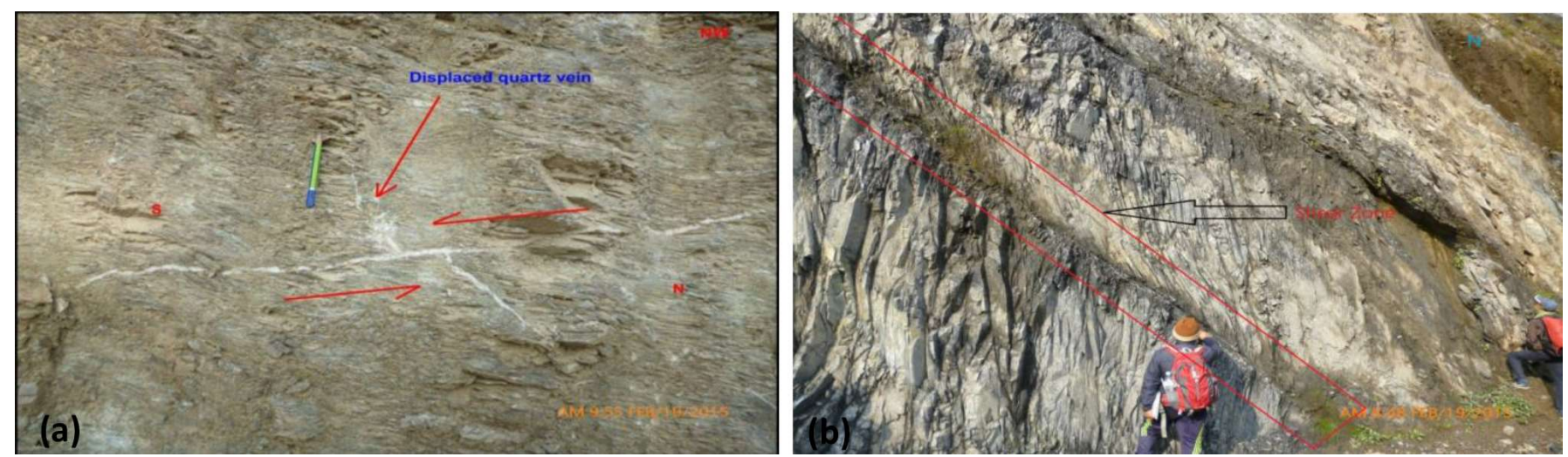

Fig. 3: (a) Field photograph showing displaced quartz veins along the strike of the foliations of the rocks in the Nourpul Formation from Talkhola, photo taken facing NW and (b) A northeast dipping shear zone exposed on the Bisnupanjargaun, facing $\mathbf{N W}$

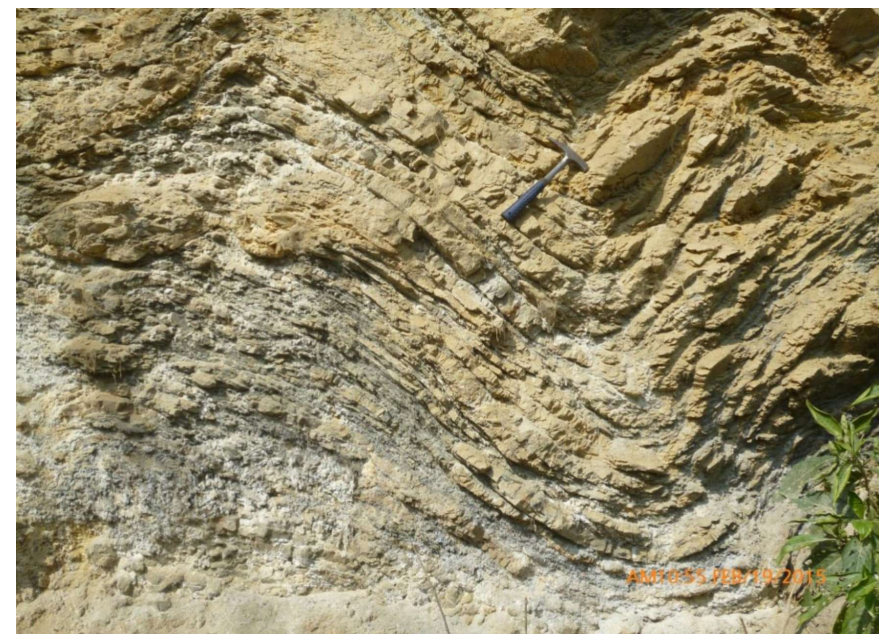

Fig. 4: Outcrop view of outcrop scale fold developed in the shearing region at Tal Khola section, facing $\mathrm{NE}$

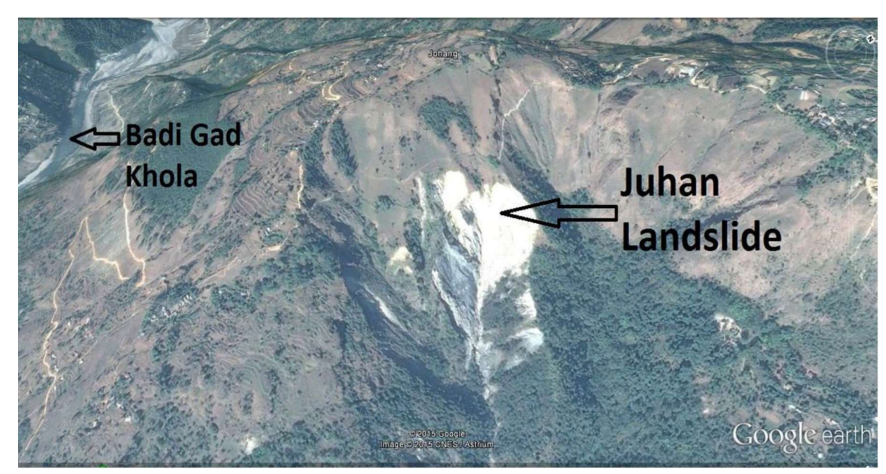

Fig. 6: The Google earth image showing Juhan landslide at the left bank hills of the Badi Gad Khola. There is a large trace of scarp of old landslide in the background.

seen in the exposure of large landslide. A fault gauge was clearly observed in the middle part of the Gultung landslide (Fig. 7). The Badi Gad Fault is supposed to pass from that region.

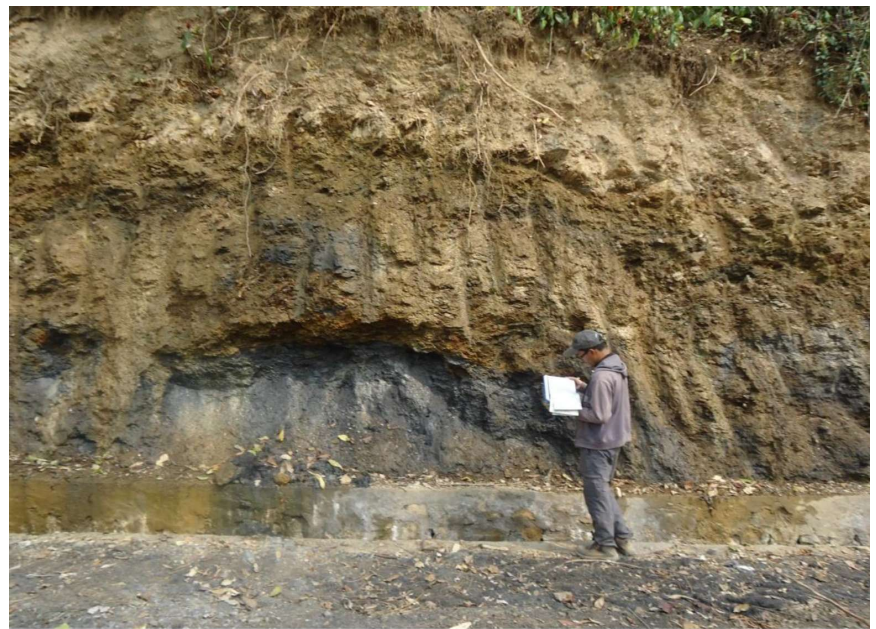

Fig. 5: Field photo showing fault gauge at Aslewa village (on the road cut section to Thulo Lumpek from Aslewa, facing $W$ )

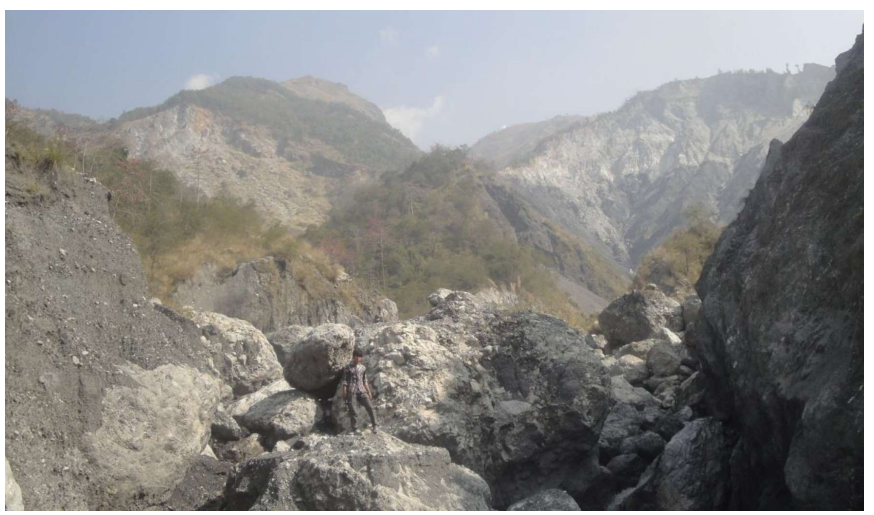

Fig.7: Outcrop view of the Gultung landslide showing shear zone. It is a large landslide in the region.

\section{Rupakot Shear Zone}

The Rupakot Shear Zone lies in uphill section of Rupakot VDC. In this shear zone a large landslide occurs. At middle part 


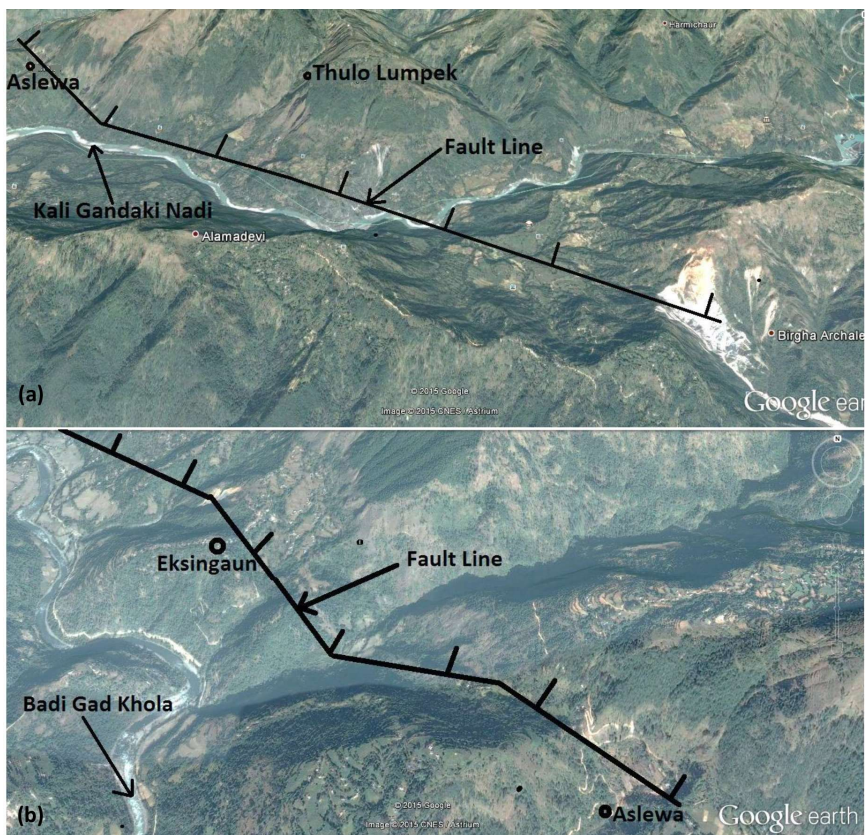

Fig. 8: Google earth images: (a) the extension of the Badi Gad Fault from Thulo Lumpek-Aslewa region and (b) a fault controlled geomorphic view at Aslewa-Eksin area

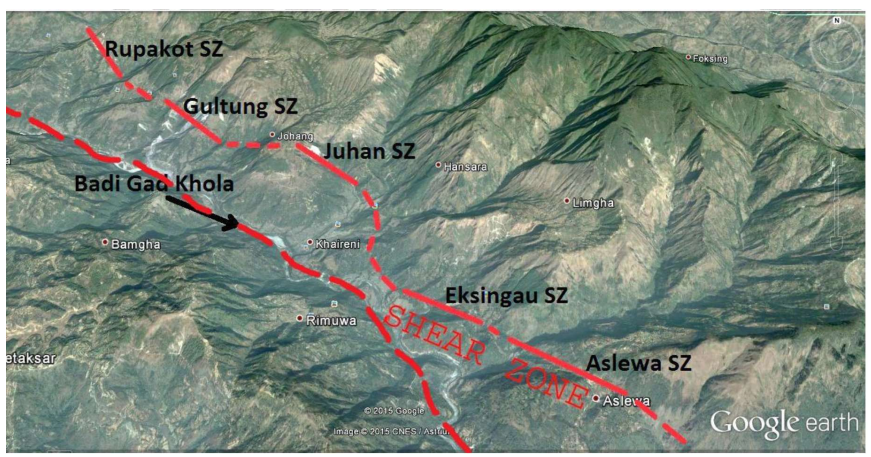

Fig. 9: The Google earth image shows a shear zone on the left bank of the Badi Gad Khola in Aslewa, Eksingau, Juhan, Gultung and Rupakot area

of this landslide has a wide zone of fault gauge. Other shear related features like breccias, sheared quart-veins, crossedmaterials and silickensides were well-observed in this area.

\section{Fault related structures under aerial photo and google earth images}

Location and extension of the faults of the present study can also be observed under the aerial photographs. The Badi Gad Fault (as the name is derived from the name of the river the Badi Gad Khola) is recognized by viewing aerial photographs in 1:50000 scale. The fault related structures can be seen in the area of the upper part of Bhanjyang gaun (Aslewa VDC) on the road section towards Thulo Lumpek showing fault gouge and breccia (Fig. 8a). Offset of river was seen at the Lumdi Khola

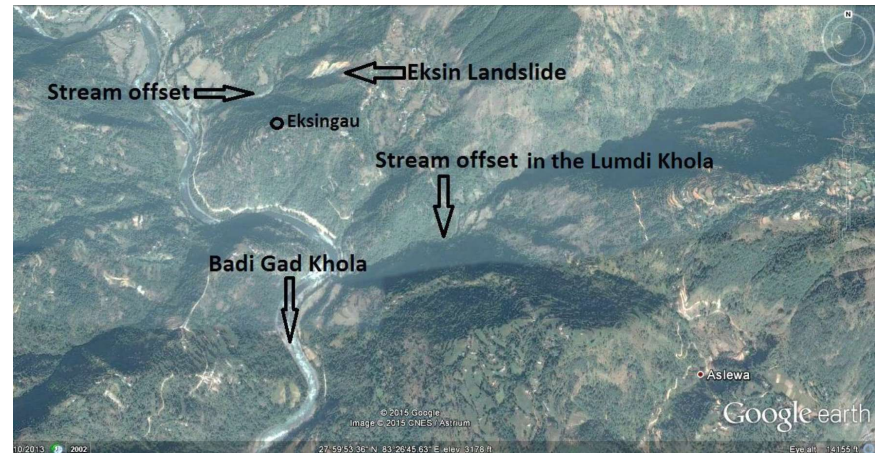

Fig. 10: A Google earth map showing stream offset in Lumdi Khola

section, about $300 \mathrm{~m}$ upstream from the confluence of the Badi Gad Khola at the Lumdi Khola (Fig. 8b). The location of successive shear zones was observed in the Kali Gandaki-Badi Khola section in a line (Fig. 10).

\section{Geomorphic features related with faults}

Several geomorphic features related with faults were studied from the different parts of the present study area. These are stream offset, fault scarp, displacement of terrace with tilting, active faults and landslides.

\section{Stream offset}

A clear stream offset is evidenced at Lumdi Khola section, about $300 \mathrm{~m}$ upstream from confluence of the Lumdi Khola and the Badi Gad Khola. Similarly, the same type of offset is seen in the foot hill section of Eksingau, left bank of the Badi Gad Khola (Fig. 10).

\section{Fault scarp}

One of the fault scarps was observed near to Bhanjyanggaun of Aslewa VDC (Fig. 11). In Badi Gad Khola section and in several active landslide areas, such fault scarps are found in different places in the Badi Gad Fault zone sections. At Eksingaun, an active landslide was observed, and a fault scarp was identified.

\section{Displacement of terraces with tilting}

To the southeast of Wamitaksar on the left bank of the Badi Gad, tilting of higher and middle terraces showed offset along the fault trace (Fig. 12). Displacement and tilting of terrace was clearly observed in the area.

\section{Active faults and landslides}

A number of landslides clustering along the Badi Gad Khola was noted in the area. In the middle course of the Badi Gad, between Wamitaksar and Rudrabeni, the fault trace runs along the Badi Gad Khola and its terraces. The fault has caused several landslides. A large northwest facing landslide has been 


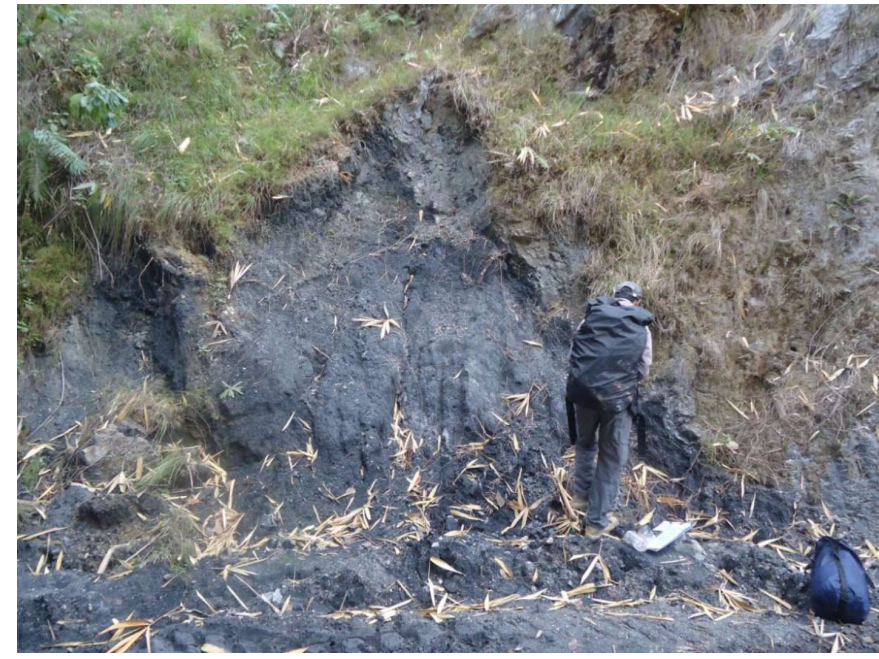

Fig. 11: Outcrop of fault scarp observed at Bhanjyanggaun (Aslewa), observer facing towards west

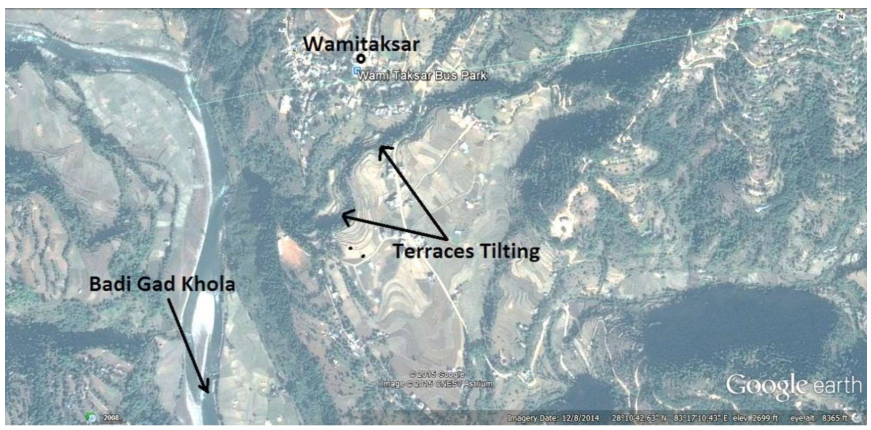

Fig. 12: Google earth image showing tilting of higher and middle terraces on the left bank of the Badi Gad Khola at Wamitaksar

mapped at Juhan, near the Ullikhola Bazar. This giant landside is geomorphologically significant along the flanks of the fault bounded mountains (Fig. 7). Another active landslide exists at Eksingun, which is northwest facing and fault trace is found to pass from that landslide.

\section{DISCUSSIONS}

\section{Badi Gad Fault: an active fault of the Lesser Himalaya}

Active faults in the Nepal Himalayas are mainly distributed along the major tectonic lines as well as older geological faults in the Lesser Himalaya. The Badi Gad Fault system coincides with the Badi Gad Fault which subdivides the Midland metasediment zone into two parts, northern one with large scale folded structures and the southern one with complicated folded structures (Nakata, 1982a). This fault system is composed of short but sharp straight fault traces along which fault scarplets, elongated fault depressions and offset of streams and terrace tilting are observed intermittently in places. Active faulting in this area is marked by a series of north-facing scarplets on the mountain flanks as well as on the river terraces of the Kali Gandaki Nadi.

The Badi Gad-Kali Gandaki Fault runs parallel to the Badi Gad Khola in the west and the Kali Gandaki valley in the central and eastern parts of the study area The Badi Gad-Kali Gandaki Fault is an out-of-sequence fault (Poudel, 2012). In the study area, the presence of active landslides, river terrace tilting and river gorging with fresh scarps are the indications of active fault. These evidences support the observation by previous researchers in different sections adjacent to this area.

\section{Field evidences of the Badi Gad Fault}

A number of shear zones are identified and mapped along a certain linear trend in the area (Fig. 2). Other indicators of fault are the displacement in quartz veins along its strike and outcrop scale features like fault gouge, silickensides, striations, densely developed quartz veins and breccias.

\section{Evidences of the Badi Gad Fault under aerial photographs}

Aerial photographs of the study area in a scale of 1:50000 were used for the study. A stereoscope was used for the viewing of 3D image for a pair of aerial photographs. To the southeast of Wamitaksar on the left bank of the Badi Gad, several streams dissecting the higher and middle terraces show right lateral offset along the fault trace. During the study of aerial photographs, focus was given on the offset of streams, fault scarps, tilting of terrace, and landslide activity in the area. At Aslewa, an excellent evidence of fault has been observed in the aerial photographs. At the right bank of the Kali Gandaki River and lower hill section of Thulo Lumpek VDC a fault line is clearly visible. A stream offset is observed at the lower section of Aslewa VDC at the Lumdi Khola (Fig. 10). At Eksingau, left bank of Badi Gad, a clear evidence of the Badi Gad Fault is identifiable on the basis of fault-controlled hillocks. Other evidence of fault can be observed in Juhan landslide. This landside is a giant and fault line has passed from the middle section of the landside.

Aerial photo shows that the Gedi Khola crosses the fault trace at Apuchaur. Diversion of several tributaries between Gaimidara and Kharbang, which dissect the higher and middle terraces on the left bank of the Badi Gad, indicates the fault trace. on the left bank of the Badi Gad towards Wamitaksar, several streams dissecting the higher and middle terraces show offset of stream along the fault trace (Figs. 13 and 14). Stream offset is another evidence of faulting at Dama. In brief, all the geological as well as geomorphic features as mentioned above are the indications of active tectonics in the area. Moreover, strike slip displacements seen in outcrops as indicated by the quartz-veins shows that the fault is strike slip in nature.

\section{CONCLUSIONS}

The following conclusions are drawn after this study:

1. The Ridi-Shantipur area consists of rock succession 


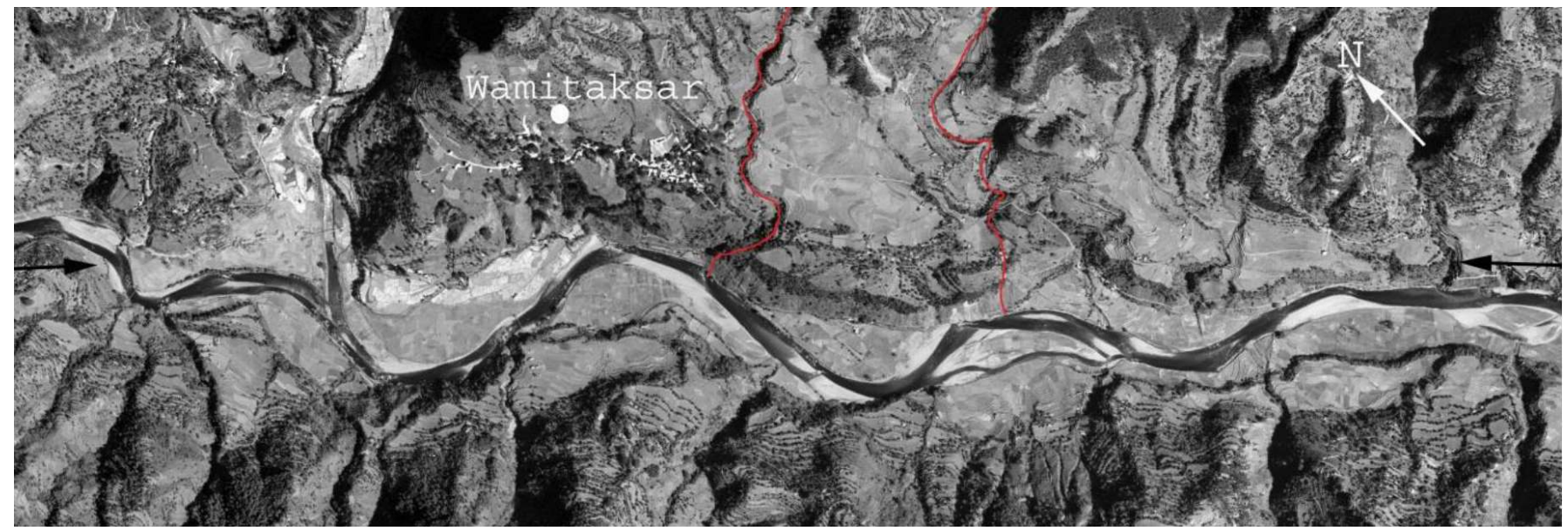

Fig. 13: Stream offset recognized along the fault trace around Wamitaksar in DEM view. Arrow indicates the position of thrust.

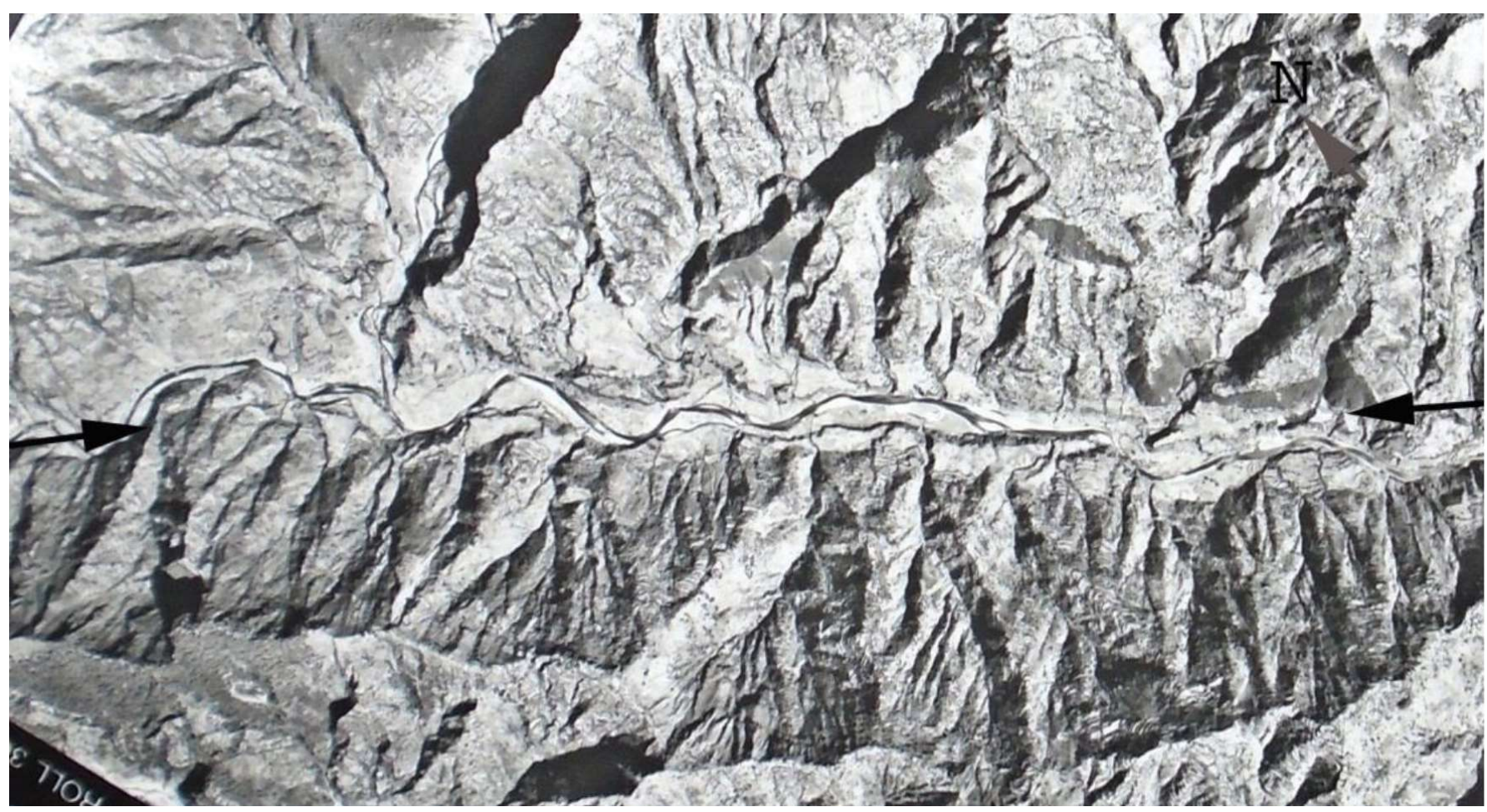

Fig. 14: Stream offset recognized along the fault trace in Wamitaksar, viewed in aerial photograph. Arrow indicates the position of fault.

of the Nawakot Group. Only the Nourpul Formation and the Dhading Dolomite are distributed in the present study area.

2. Several geological as well as geomorphological evidences are found to trace out the Badi Gad Fault in the region. These include the Tal Khola Shear Zone, Aslewa Shear Zone, Eksingau Shear Zone, Juhan Shear Zone, Gultung Shear Zone and Rupakot Shear Zone in addition to other several zones. All these shear zones are confined to a linear trend locating at the left side of the present course of the Badi Gad Khola. Field evidences of these shear zones can be marked by the fault gauge, fault breccia and slickensides.

4. More commonly the Badi Gad Fault passes through the geological contact of the Nourpul Formation and the Dhading Dolomite, as this represents the weak region in the area.

5. Several spring lines are developed through the fault region. This is also one of the geomorphic criteria to recognize a fault zone.

6. Several geomorphic features like fault plane depressions, stream offset or river course diversion at the fault 
zone, terrace tilting, fault scarps, activity of fresh landslide, river gorging with fresh cliffs etc. are the strong evidences of presence of active fault in this area.

7. Fault plane depression runs from Alamdevi-Aslewa to Eksingau area and continuously runs further upstream of the Badi Gad Khola. Stream course diversion is found at the Lumdi Khola, small tributaries at foothill side of Eksingau and Jumdi Khola sections from east to west of the Badi Gad Khola. Similarly, fault scarps were observed in Bhanjyang gaun of Aslewa VDC and terrace tilting was observed in the Wamitaksar area. These geomorphic features were clearly observed under the aerial photographs as an indication of active tectonics.

\section{ACKNOWLEDGEMENTS}

Authors are grateful to the Central Department of Geoloy for field equipments and laboratory facilities. We acknowledge Amar Singh Rai, Bikash Ranabhat, Byapak Yogal, Manish Singh Chaudhari, Ram Sundar Pyakurel, Shrawan Shakya, Surya Shekhar Khadka, and Sunil Bikram Thakuri for their support in the field work.

\section{REFERENCES}

Amatya, K. M. and Jnyawali B. M., 1994, Geological map of Nepal. Kathmandu, Department of Mines and Geology. ICIMOD, SCALE 1:1,000,000.
Arita, K., Hayashi, D. and Yoshida, M., 1982, Geology and structure of the Pokhara-Puthan area, central Nepal. Journal of Nepal Geological Society, v. 2, Special Issue, pp. 5-30.

Bloom, A.L., 2002, Geomorphology. Prentice-Hall of India Private Limited, New Delhi.Third edition, 482 p.

Hagen, T., 1969, Report on the Geological Survey of Nepal -I (Preliminary Reconnaissance). Denkschr. Svhweiz Naturf. Gessell., Bd., v. 86, pp. 1-185.

Nakata, T., 1982, A Photogrammetric study on active fault in the Nepal Himalayas. Journal of Nepal Geological Society, v.2, Special Issue, pp. 67-80.

Nakata, T., Iwata, S., Yamanaka, H., Yagi, H., and Maemoku, H., 1984. Tectonic Landforms of Several Active Faults in the Western Nepal Himalayas. Jour. of Nepal Geol. Soc., v. 4, (Sp. Issue), pp. 177-200.

Paudel, L. P., 2012, Thin-skinned tectonics of the TansenPokhara section, central Nepal Himalaya. Jour. Nat. Hist. Mus., v. 26, pp.15-28.

Paudyal, K.R; 2014, Geological and petrological evolution of the Lesser Himalaya between Mugling and Damauli, central Nepal, PhD thesis, TU, 226 p.

Stöcklin, J. and Bhattarai, K.D., 1977. Geology of Kathmandu area and central Mahabharat range Nepal. Department of Mines and Geology Kathmandu, Nepal, 86p.

Stöcklin, J., 1980. Geology of the Nepal and its Regional Frame, journal of the Geol. Soc. of London, v. 137, pp. 1-34. 
